\title{
FINANCIAL LITERACY AS A PART OF LIFELONG EDUCATION
}

\author{
Hana Mohelska and Vaclav Zubr \\ University of Hradec Kralove, Faculty of Informatics and Management, Rokitanskeho 62, 50003 Hradec Kralove, \\ Czech Republic
}

\begin{abstract}
This article is focused on the financial literacy of elementary students as a part of a lifelong education. The introduction covers the concept of financial literacy and the development of financial education in EU countries and in the Czech Republic. It also presents the strategic documents that have been gradually published. It turns out that there is a gap for research in the field of financial education strategy for elementary and school students and its coherence with lifelong education. The national strategic plan focuses mainly on the high school students, but the practice show that it should start with students that are in the compulsory education. The results of the OECD's research called Program for International Student Assessment (PISA) show educators and policy makers the quality and equity of learning outcomes achieved elsewhere and allow them to learn from the policies and practices applied in other countries. The goal of this article is to evaluate the project of financial education and analyze the current situation in the financial literacy of the elementary school students in Czech Republic in comparison with foreign countries. The article searches for the strengths, opportunities and threats using the method of SWOT analysis. Based on the obtained results it formulates conclusions and recommendations.
\end{abstract}

\section{KEYWORDS}

Financial Literacy, Financial Education, SWOT Analysis, Lifelong Education

\section{INTRODUCTION}

Financial literacy is the education and understanding of various financial areas including topics related to managing personal finance, money and investing. This topic focuses on the ability to manage personal finance matters in an efficient manner, and it includes the knowledge of making appropriate decisions about personal finance such as investing, insurance, real estate, paying for college, budgeting, retirement and tax planning (Kenton, 2019).

National surveys show that young adults have amongst the lowest levels of financial literacy. This is reflected by their general inability to choose the right financial products and often a lack of interest in undertaking sound financial planning. Even from an early age, children need to develop the skills to help choose between different career and education options and manage any discretionary funds they may have, whether from allowances or part time jobs. These funds may entail the use of savings accounts or bank cards. In 2005, the OECD recommended that financial education start as early as possible and be taught in schools. Including financial education as part of the school curriculum is a fair and efficient policy tool. Financial education is a long term process. Building it into curriculums from an early age allows children to acquire the knowledge and skills to build responsible financial behavior throughout each stage of their education. This is especially important as parents may be ill-equipped to teach their children about money: levels of financial literacy are generally low around the world. In 2012, financial literacy is an optional component of the OECD Program for International Student Assessment (PISA). PISA currently tests the attainment of 15 -year-olds in mathematics, reading and science across 65 countries. The introduction of a financial literacy assessment will result in a unique international benchmark on the level of financial literacy of young people. The rich data will enable detailed investigations of the main factors associated with financial literacy levels and will help to identify policy measures that can be employed to improve levels in the future (Atkinson et al., 2015). 
The OECD's Principles and Good Practices for Financial Education and Awareness recommend that financial education start as early as possible and be taught in schools. Including financial education as part of the school curriculum is a fair and efficient policy tool. Financial education is a long-term process. Building it into curriculums from an early age allows children to acquire the knowledge and skills to build responsible financial behavior throughout each stage of their education. This is especially important as parents may be ill-equipped to teach their children about money and levels of financial literacy are generally low around the world.

The OECD Program for International Student Assessment (PISA) examines not just what students know in science, reading and mathematics, but what they can do with what they know. Results from PISA show educators and policy makers the quality and equity of learning outcomes achieved elsewhere and allow them to learn from the policies and practices applied in other countries. PISA 2015 Results (Volume IV) (OECD, 2017) provide Students' Financial Literacy, is one of five volumes that present the results of the PISA 2015 survey, the sixth round of the triennial assessment. It explores students' experience with and knowledge about money and provides an overall picture of 15-year-olds' ability to apply their accumulated knowledge and skills to real-life situations involving financial issues and decisions. Many young people face financial decisions and are consumers of financial services in this evolving context. As a result, financial literacy is now globally recognized as an essential life skill. Around one in four students in the 15 countries and economies that took part in the latest OECD Program for International Student Assessment (PISA) test of financial literacy are unable to make even simple decisions on everyday spending, while only one in ten can understand complex issues, such as income tax.

Around 48,000 15 years old took part in the test, which evaluated the knowledge and skills of teenagers around money matters and personal finance, such as dealing with bank accounts and debit cards, or understanding interest rates on a loan or mobile payment plan.

\subsection{Financial Literacy Components}

Financial literacy as the management of personal/family finances includes the three following components:

- Monetary literacy represents the competences necessary for the management of cash and non-cash money and the transactions with them, and the management of the instruments intended for that purpose (e.g. current account, payment instruments, etc.).

- Price Literacy represents the competences necessary for understanding price mechanisms and inflation.

- Budget Literacy provides the competences necessary for the management of the personal/family budget (e.g. ability to work with budget, set financial objectives and decide on the allocation of financial resources) and includes the ability to manage different living situation in financial terms. In addition to the things described above, budget literacy also includes two specialized components:

- Management of financial assets (e.g. deposits, investments and insurance)

○ Management of financial liabilities (e.g. loans or leasing).

This requires, in both cases, the orientation in the market of various complicated financial products and services, the ability to compare individual products or services with each other and to choose the most suitable ones with regards to the specific life situation (NSFV, 2018).

\subsection{Lifelong Learning in Organizations in the Czech Republic Regarding the Europe 2020 Strategy}

The framework of actions for the lifelong development of skills and qualifications, adopted by the European social partners in March 2002, emphasises that, in order to maintain competitiveness, businesses need to adapt their structures more rapidly. The increase in teamwork, alignment of hierarchies, decentralisation of competences and greater need for the ability to multitask contribute to the development of "learning organisations". The ability of organisations to define the abilities, mobilise, recognise and support their development for all employees is the cornerstone of new strategies to increase competitiveness (Zubr, Mohelská, 2017). 
The European Union (EU) member states have historically developed different approaches to the financing, management and evaluation of educational activities. The field of education therefore is not among the EU's common policies. Unlike the common monetary and customs policy, the education policy has the status of a so-called 'complementary' policy. This means that EU activity in this area does not directly affect national education policy but is limited to supporting member states. The EU institutions can only grant member states recommendations (Cankaya, et al., 2015). According to the Lifelong Learning Strategy of the Czech Republic (CZ) (MEYS, 20), lifelong learning presents all possibilities for learning (whether in traditional educational institutions inside the education system or otherwise) as a single interconnected unit that facilitates diverse and numerous transitions between education and employment and which provides the same qualifications and competence in various ways and at any time during a person's lifetime (Cheng, 2003; Veteška and Tureckiová, 2008). Based on the above, it can be concluded that the essence of the EU's efforts in education lies in its systematic and large-scale financial support given to individual countries and regions.

\section{METHODOLOGY}

To obtain the required findings and conclusions of the present study, we conducted a content analysis of national and international strategic documents. We simultaneously used a comparative method to link our findings, or more precisely the students' knowledge of financial literacy subjects with relevant binding documents. As a source of information to perform the analysis of the project, publicly available information was used, as well as information from the CSOB company's intranet and from the ambassadors themselves.

Internal information

Detailed information about project Financial education ČSOB for schools, which is analyzed in the practical part of the work, were found using the in-house resources. The project does not have a strategic plan, only a tactical plan for the maximum period of one year. The main indicators of this plan, which also form the objectives, are the numbers of the ambassadors involved, the lessons taken, the schools involved and the number of students who have completed the lessons. Unfortunately, not all indicators are determined for each individual year.

SWOT analysis

SWOT analysis is a universal analytical technique for evaluating internal and external factors that influence the success or failure on the market. The core of this analysis is the identification of key factors within, meaning what the organization (or part of it) is good at and what it does wrong. It is equally important to know the key factors of the external environment. The goal is to discover and then reduce weaknesses, promote strengths, look for new opportunities and know the project's threats. The key to success is to exploit opportunities and minimize threats.

\section{PROCEDURE FOR THE INTRODUCTION OF THE FINANCIAL EDUCATION IN CZECH REPUBLIC}

For the program to be successful in the introduction of financial education, there must be an institution to provide the project, lead, define priorities, take care of its promotion, co-ordinate other stakeholders and much more. Only one institution cannot cope with all these activities. It is therefore desirable to involve other key participants, such as the Ministry of Education, Youth and Sports, representatives of governments, representative of the school system - universities, faculties, elementary schools, high schools, even kindergartens as well as representatives of financial institutions - banks, insurance companies, investment companies, etc. The involvement of other participants is also important in order to increase credibility, increase the number of experts and the amount of resources available. At an imaginary peak, although the authors of the text in the ideal case see the Central bank however in the Czech Republic the position is held by the Ministry of Finance (Fabris, Luburić, 2016). 


\subsection{Resolution of the Czech Republic Government}

In the Czech Republic everything started on 7. December 2005, when a task for the Deputy Prime Minister and Treasury Secretary was defined at the meeting of the Government of the Czech Republic - to create an expert working group on the financial sector composed of representatives of financial institutions, consumer organizations, Ministry of Finance and Ministry of Industry and Trade. And a common task for ministers of finance, education and industry and trade- to prepare the system of building the financial literacy in elementary schools and high schools. Based on the resolution, the Expert group for financial sector, which included three working groups, was established. For this work, the most important sub-group is the Working Group on Financial Education ("PSFV" - Pracovní skupina finančního vzdělávání), which started its activities in August 2006. The initial goal of PSFV was to propose measures to increase financial literacy and improve the process of financial education, which has fulfilled a later discussion of financial literacy standards and financial education strategy (PSFV, 2010).

\subsection{Research of the Financial Literacy Level}

In their text Fabris and Luburić (2016) mention that the opening point of the strategy should be to answer the questions: "Where are we now?" and "Where do we want to be in the future?". The answer to the first question can be found by means of a national survey, which will later allow for a simple comparison of the initial state and fulfilment of predetermined targets (2016).

That's why, in 2007, Ministry of Finance commissioned a quantitative research process to the company STEM/MARK to map the basic level of financial literacy based on a subjective assessment of the population and to ascertain the assessment of its own level of education and the need for further training in financial services among consumers. The survey was conducted on the adult population of the Czech Republic through standardized personal interviews with the help of questionnaires (STEM/MARK, 2007).

Research has shown that the adult population of the Czech Republic evaluates the level of its financial literacy by an average mark of 3, about half of them is satisfied with the level of its knowledge and half of them are not or does not know. People with degree, with higher household incomes and private entrepreneurs have evaluated themselves with higher marks. An interesting observation is also that the vast majority $(81 \%)$ of the respondents noted that they didn't get any knowledge of financial and bank orientation in school and almost all (93\%) of them would welcome being able to learn the basic concepts in this area in the high school and less than half would have included this curriculum at the elementary school (STEM/MARK, 2007).

\subsection{Financial Education Strategy}

Based on the findings of the aforementioned survey, in the second half of the year 2007 the already mentioned financial education strategy was established, aiming to create a coherent system of financial education for increasing the financial literacy level in the Czech Republic. The proposed financial education process has been given a two-pillar structure that should involve the entire population. This structure defines the main target groups in the framework of initial education and further education of the adults (PSFV, 2014).

\subsection{System of Building Financial Literacy on Elementary Schools and High Schools}

In December 2007, a strategic document System of building financial literacy on elementary schools and high schools was completed, describing the process of implementing financial education in initial education. Its integral part are the financial literacy standards, which set the financial literacy target level for each of the degrees of education, while the financial literacy level set in the standards for the last year of high school is also considered to be the financial literacy level of the adult consumer.

The document further imposes the inclusion of these standards in the framework educational programs (referred to as "the RVP" - Rámcový vzdělávací program), the development of methodological recommendations to schools, the inclusion of financial education topics in education programs under the 
system of further education of pedagogical workers and the future revision of this document in line with the evolution of financial markets and student's needs. The financial literacy teaching got to "RVP" high schools in 2009 and the "RVP" elementary education in the year 2013. The Czech Republic thus became one of the first countries in which compulsory teaching of this type was introduced (Ministry of Finance of the Czech Republic, 2018).

\subsection{National Strategy for Financial Education}

The Organization for Economic Co-operation and Development (OECD) and the European Commission recommended the creation of national strategies approved by the governments of the individual states to raise awareness on the need for financial education and the necessity of establishing a single coordinated system. The original strategy was not a government-approved concept, so the Ministry of Finance, in cooperation with the Ministry of Education, Youth and Sports and the Czech National Bank, came up with its updated version. In May 2010, this update was adopted under the name National financial Education Strategy (Ministry of Finance of the Czech Republic, 2018).

\section{FINANCIAL EDUCATION ČSOB FOR SCHOOLS PROJECT ANALYSIS}

One of the cornerstones of ČSOB's corporate philosophy is socially responsible behavior. It consists of responsible business, philanthropy in the form of various grant programs for non-profit organizations and employee involvement. In accordance with their socially responsible activities, or the Corporate Social Responsibility (CSR), ČSOB's focus is on four main pillars of responsible Business (ČSOB, 2018):

- financial literacy and education,

- longevity,

- business support,

- environmental responsibility.

Financial literacy and financial education are the most natural issues for the bank and within this category the analysed project Financial education ČSOB for elementary schools can be found.

\subsection{The Project's Characteristics}

Since 2016, the Financial education ČSOB for schools has been offering complementary teaching of financial literacy in elementary and high schools. The content of the teaching is created following the RVP published by the Ministry of Education, Youth and Sports. The intention is to diversify standard financial education with an interactive and entertaining lecture, which is usually conducted by the representatives of the bank from the region. It is also important to mention that this is free of charge for the school, as the project ambassadors are volunteers (ČSOB, 2018).

\subsection{Goals of the Project}

The goal of the program is to prevent the "threat" of low financial literacy inside the population and promote its development among children and associated communities. In ČSOB, they believe that a higher level of financial literacy and financial education not only enriches the lives of individuals, but also contributes to healthy economic growth in society. Consumers with good financial knowledge and healthy personal finances require better and more efficient products and solutions, which contributes to increasing competition, innovations and quality of products in financial markets.

The target group were the elementary and high school students, who are thought financial literacy in the framework of the standard curriculum. Secondarily, this project offers the possibility of extending knowledge and education to teachers who teach this topic. 


\section{PROJECT'S SWOT ANALYSIS - RESULTS}

\subsection{Strengths}

A strong aspect of this project is excellent knowledge of the financial environment. Many project's ambassadors meet clients who come to address their financial situation almost daily. As a result, lecturers can identify areas of financial education in which the company has the largest gaps, focusing the lectures on these shortcomings. The bank wants clients who have good financial knowledge and healthy personal finances because such clients can cover their commitments.

This project has a great chance to succeed and endure, as it has a strong partner in the form of a financial institution with a long-term interest in increasing the financial literacy within corporate social responsibility (CSR). The life span of many other projects is limited in time by provided subsidies and grants.

Usually the teaching is realized directly by the representatives of the bank from the region and from the branches who know the environment. Many times, they even have a personal relationship for the given area, the city or the school, which makes a positive impression. And although the emphasis is on regional coverage, they can also cover the teaching centrally.

The involvement of two well-known Czech youtubers to help alert children about cybersecurity. Youtubers are perceived by today's children as celebrities, heroes as they believe, take their views as their own and overall try to imitate them. So, if such a person encourages the right behavior in the digital world and presents deterring cases in his posts, he teaches the children through the form of their daily entertainment. Moreover, these young consumers do not even realize that they are subconsciously learning while watching video.

Schools like to choose this project, because it is offered completely free of charge and has very positive responses and references.

\subsection{Weaknesses}

The projects use the marketing insufficiently in order to inspire an interest in new people. Almost the only presentations that can be seen are interviews given for articles. While the company's YouTube channel is trying to create videos, they have on average only around 200 views (April 2019).

Another weakness is also related to propagation, but it is not about inspiring an interest in new people, but a general perception of the company by the public. The project should publish its work and achievements more, because thanks to that, the ČSOB can be more perceived as a socially responsible company.

The project does not include any possibility to assess whether the financial literacy of the schooled students has been improved. Ambassadors only subjectively assess the improvement of the overall literacy level compared to the beginning of the year 2016.

It might be also perceived as a weakness that a lot of lecturers have no previous experience with giving lectures and teaching children. Although ČSOB offers the possibility of internal training, it is a one-time issue. The most helpful thing would be giving actual the lectures, which, with the increasing number of given lectures, would lead to gaining the necessary skills and self-esteem.

Since the project was launched only three years ago (in 2016), there is not too much room for evaluating its effectiveness and chosen strategy.

The weakness of the project is also the fact that they do not have a strategic plan developed to determine specific targets for a period longer than one year.

\subsection{Opportunities}

The originally side topic of cybersecurity is becoming more and more important due to fact that it's a current issue, thus creating a space for the inclusion of another field. This new field could be medial education, which is currently included among the cross-cutting themes.

Cross-cutting topics are a compulsory part of basic education, which represent the current world problem circuits. There are several ways of implementing these topics. In particular, the following options are recommended: integration into thought subjects, introduction of a separate subject, or teaching through projects. Ideally, multiple options should be linked. Therefore, if the school would implement the teaching through the ČSOB's project, it would use the third method - teaching through projects (CSOB, 2918). 
Media education is based on the knowledge that mass and network media (periodical press, radio, television, internet media and social networks) are currently a significant factor in both primary and secondary socialization. In basic education, media education offers basic knowledge and skills related to media communication and work with media. These represent a very important source of experiences and knowledge for an increasingly large audience. It is important to be able to process, evaluate and use the stimuli that come from the outside world to utilize an individual in the society. The stimuli from the media are the most important ones coming from the outside world (Němcová et al., 2011).

The whole project could then become a program to support the most recent problems of the society, which are coming into the cross-cutting themes. The project could include teaching financial literacy, digital literacy (cybersecurity) and medial literacy.

The following opportunity responds to the above-mentioned weakness of project's small amount of views for videos published on its YouTube Channel. Creating videos tends to be a costly thing, so it's a shame not to bring the desired effect. It could help to share the videos to ČSOB's other social networks. Whether it's an official site for the whole business or it's the pages of subsidiary companies or other departments. For example, Facebook and Instagram are the best-known social networks.

We will stay on YouTube channel and outline another option to improve the project. Animated series Filip in school has only four episodes. Other parts such as one the on the subject of a complaint that falls within the topic of consumer protection or the demonstration of the execution process.

Another opportunity is the acquisition of accreditation in the system of continuous education of the pedagogical workers, which is awarded by the Ministry of Education, Youth and Sports. In the updated version of the National financial education strategy, lecturers appear as an additional target group, which could also be reflected in the project's goals. Pedagogical workers can pass on the acquired knowledge and experience in the long term, which will multiply the effect of the project.

Teaching is currently ongoing in the school environment. The lecture at the camp or workshop is only an exception. Other possible places to give lectures at are e.g. children's homes, educational institutes, suburban camps, etc. A large proportion of young people, after leaving a child's home or institute, are getting into an existential problem, which may occur be due to the low level of financial literacy. However, as far as the institutions are concerned, it would be advisable for those ambassadors who already have several hours of teaching and ideally have previous experience working with this vulnerable group of children to attend these places.

Further spreading of awareness not only about this project, but also other CSR activities of the ČSOB group in the form of advertising spot is another opportunity. Advertisement is a very common and popular form of propagation, the length of which usually varies between 20 and 30 seconds. Most often an advertising spot can be seen or heard in audiovisual media, i.e. on television, radio, or on the internet. It can be a short spot played before another video, on servers such as YouTube, Stream.cz or before video on news portals.

If there is mutual satisfaction after the lecture, it would be good for lecturers to try to establish further cooperation, whether of single or long-term nature. It could be a one-time teaching of the same class, with only a different theme. The long-term agreement could consist of an annual meeting, for example, with 5th class of elementary school. The schools could plan ahead, and the lessons of the remaining circuits would be adjusted accordingly. For the project, this would result in a certain minimum number of hours to be taught in the next year, making it easier to make plans.

\subsection{Threats}

The main threat is the existence of a lot of similar projects.

Another threat is any possible scandal around the ČSOB group. Although it might not have a direct link with the project, it would probably harm it as well. A person who does not know the project could be able to make the connection, because the name of the company is included in the name of the project itself. Unfortunately, any negative reviews and emotions are spreading faster and easier than the positive ones.

\section{CONCLUSIONS AND RECOMMENDATIONS}

Financial literacy is now an essential part of our lives. The company soon understood that it was necessary to start the financial education as soon as in primary school. As a result, children will learn the correct handling of money and understand, at least the basics of how they work, and what obstacles await them. 
The draft of the strategic plan contains recommendations on the implementation of teaching in the area of South Bohemia, Vysočina region and North Moravia and Silesia, as these regions are falling behind on the project map. It is also recommended to establish continuous cooperation with schools already involved throughout the Czech Republic.

Another point of the strategic plan is to reach out to an influencer, which would complement the two colleagues already involved. The main theme to be discussed in the project is cybersecurity, which is directly related to the digital space on which they operate.

In addition, the project must focus on better promotion and marketing. One of the identified options is the sharing the videos previously published on YouTube, the creation of new episodes of the Filip at school series, which is also located on YouTube channel and possibly the creation of a short advertising spot, which could be played as an advertisement before other videos on the Internet or on TV.

An important point in the strategy is the inclusion of a new subject- medial education, which could be as successful as the topic of cybersecurity. Other opportunities are the expansion of target groups on seniors and pedagogical workers and the addition of other places for the realization of the teaching.

\section{ACKNOWLEDGEMENT}

The paper was written with the support of the specific project 2019 grant "Determinants of cognitive processes impacting the work performance" granted by the FIM UHK and thanks to help of student František Hašek.

\section{REFERENCES}

Atkinson, A., F. Messy, L. Rabinovich and J. Yoong (2015), Research and Literature on Financial Education for Long-term Savings and Investments, OECD Working Papers on Finance, Insurance and Private Pensions, No. 39, OECD Publishing. http://dx.doi.org/10.1787/5jrtgzfl6g9w-en.

Cankaya, S., et al., 2015. The Educational Policy of European Union. Procedia - Social and Behavioral Sciences, 174, 886-893.

ČSOB， 2018， https://www.csob.cz/portal/documents/10710/316999/financni-vzdelavani-csob-pro-skoly.pdf, last accessed 2019/07/22.

Fabris, N., Luburić, R., 2016. Financial Education of Children and Youth. Journal of Central Banking Theory and Practice, 5(2), 65-79.

Cheng, Y. C., 2003. Quality assurance in education: Internal, interface and future. Quality Assurance in Education Journal, 11(4), 202-213.

Kenton, W., 2019. Financial Literacy, https://www.investopedia.com/terms/f/financial-literacy.asp, last accessed $2019 / 07 / 23$.

NSFV - Národní strategie finančního vzdělávání 2.0: změnou chování k převzetí odpovědnosti za svou finanční

prosperitu. 2018. https://www.psfv.cz/assets/cs/media/PSFV_Konzultace_2018-05-15_NSFV-20-draft1.docm, last accessed 2019/01/24.

Ministry of Finance of the Czech Republic, 2018. Návrh revidované Národní strategie finančního vzdělávání, https://www.mfcr.cz/cs/o-ministerstvu/verejne-diskuze/2018/navrh-revidovane-narodni-strategie-finan-31870, last accessed 2019/07/22

Ministry of Finance of the Czech Republic, 2017. Standard finanční gramotnosti, https:/www.mfcr.cz/cs/aktualne/aktuality/2017/standard-financni-gramotnosti-29163, last accessed 2019/07/22.

PSFV - Ministry of Finance of the Czech Republic, 2014. Role PSFV a její činnost. https://www.psfv.cz/cs/proodborniky/pracovni-skupina-pro-financni-vzdelavani/role-psfv-a-jeji-cinnost, last accessed 2019/07/18.

MEYS - Ministry of Education, Youth and Sports, 2010. ET 2020: a strategic framework of European cooperation in education and training. MEYS, Department for EU affairs EU, Prague.

Němcová, Z., et al., 2011. Issues of Financial Literacy Education. Procedia - social and behavioral sciences, 28, 365-369.

OECD (2017), PISA 2015 Results (Volume IV): Students' Financial Literacy, PISA, OECD Publishing, Paris. http://dx.doi.org/10.1787/9789264270282-en

STEM/MARK, 2007. Research for Ministry of Finance of the Czech Republic. Research final report 2007, https://www.mfcr.cz/assets/cs/media/Odborne-vyzkumy_2007_Zaverecna-zprava-z-vyzkumu-plne-zneniSTEMMARK-2007.pdf, last accessed 2019/07/29.

Veteška, J., Tureckiová, M., 2008. Competencies in education (in Czech). Grada, Prague.

Zubr, V., Mohelská, H., 2017, Selected Factors Supporting the Learning Organization. Emerging Technologies for Education. SETE 2017. Lecture Notes in Computer Science. Springer, Cham, 195-202. 